\title{
Using Current Events to Test and Teach Critical Theory
}

\author{
James Curiel, Robert K. Perkins, Austin Ashe \\ Norfolk State University, USA
}

\begin{abstract}
What happens when your graduate class realizes Peter Marcuse's writing from 2012 was taking place in the 2016 Trump Presidential campaign? Marcuse theorized during an economic crisis the dispossessed will either swing towards egalitarianism and rights for all, or they will swing towards fascism and the elimination of rights for scapegoat groups. Marcuse postulated the dispossessed could be manipulated to support fascism through rhetoric touting: antiabortion, gun rights, homophobia, racism, antiimmigrant sentiment, religious fundamentalism, war mongering and false patriotism. The class realized the 2016 Trump campaign was mirroring Marcuse's list of manipulation, so, two independent variables from Marcuse's list, racism and guns rights, were tested to see if they had a correlation to states having a higher Trump voting percentage in the 2016 Presidential election. This research contributes to the social sciences by demonstrating the applicability of critical theory to real world phenomenon, and by contributing support to the accuracy of defining the Trump campaign as fascist.
\end{abstract}

\section{Introduction}

What happens when your graduate class in Urban Affairs is reading critical theory, and everyone realizes Peter Marcuse's writing from 2012 is taking place in the 2016 Trump Presidential campaign? Marcuse theorized during in an economic crisis the dispossessed and alienated will either swing towards egalitarianism and push for rights for all people, or they will swing towards fascism and advocate the elimination of rights for scapegoats [1]. Marcuse hypothesized the wealthy manipulate the dispossessed to embrace fascism by using emotion based rhetoric supporting a platform of anti-abortion, gun rights, anti-tax, homophobia, racism, antiimmigrant sentiment, religious fundamentalism, family values, war mongering, false patriotism, sports fanaticism, and home ownership [1]. As the class read Marcuse's list of manipulation it read like a blue print for the Trump presidential campaign.

Debate rages over whether Trump's presidential campaign and presidency is fascism. Some, like Cobbler, hedged their bets calling Trump a "protofascist," while others, such as Christina, unequivocally stated Trump was a full-blown fascist," and still others, such as Gilmore, who argued Trump was not a fascist because Hitler had a "coherent worldview" while Trump is philosophically inconsistent [2], [3], [4], [5], [6], [7].

The 2016 Trump campaign served as a learning opportunity to test Marcuse's theory. Robert Paxton, widely considered to be the "father" of fascist studies, was used to define fascism as, "popular feelings about master races, ....and their rightful predominance over inferior people... [based] upon the leader's mystical union with the history of his people [6]. Thus, domination of others and adoration for the leader are the only factors that need to be consistent, and in fact, a tell-tale sign of fascism is a group's political program is a capricious ideological quilt dependent upon the whim of the leader's political expedience.

Marcuse's theory on fascism was tested by using Presidential voting totals to see if there were correlations to two items on the list of manipulation, racism and gun rights. Our method for testing is described in further detail in the methods section.

\section{Literature Review}

As Benjamin Franklin was walking out of the Constitutional Convention in 1787, someone shouted out, "Doctor, what have we got? A republic or a monarchy?" Franklin responded, "A republic, if you can keep it" [8]. The current political climate has garnered a stampede of intellectual curiosity and studies about America's republic and whether it is being challenged by a fascist ideology. Over time, political analysts expanded the historical context of fascism as a sole Mussolini leadership style to an analytic category for the Heads of State [9]. Over 100 years later, academicians in all disciplines have reexamined the term fascism in a quest to understand how power is conducted in contemporary America [8], [10], [11], [12]. Today's politicians often use the rhetoric of moving towards a socialist society or dictatorship. Even more startling, some argue that the very soul of America is at stake making is vulnerable to authoritarianism [13].

Fascism is a term coined by Benito Mussolini to define Italy's regime in the early 1900s. It is a social and political movement/phenomenon that promotes the idea of a forcibly monolithic regimented nation under the control of an autocratic ruler [10]. The word fascism comes from fascio, the Italian word for bundle, which in this case represents bundles of people [11]. "Mussolini thought that democracy was 
a failed system. He also argued that liberty of expression and liberty of parties was a sham and that fascism would organize people under one state power" [14]. Other theorists of his time offered counter-arguments.

Foucault found that fascism would be problematic for freethinking people and a democratic society. He argued that the primary focus of the modern state to secure its social body, or its population, through various techniques, including the use of knowledge [15]. To Foucault, the state engenders the conditions that shape peoples' understanding of their world around them by using institutions that use forms of knowledge that have physically coercive effects on people. Foucault acknowledges that the state is more powerful than its people; however, the state did not have sole power over its people [16]. Marx posited that the state has too much power, which places the working class in bondage and limits their opportunities to be free [10]. Thus, the proletariats would gain class-consciousness after realizing they were being exploited by receiving little to no rewards for their labor [17]. Contrarily, Mussolini's ideological underpinning was that people would be freer under fascism because they will not have any class-consciousness; thus, people are devoted to the nation, not individualism. It is nation over class [10] [13]. Academicians are comparing Mussolini's ideological approach to power to Trump's fascist tendencies.

Fascism, like other ideologies such as socialism or liberalism, is a political movement that can mean different things based on the social context and political circumstances [16]. The consequence is that no academic consensus for definition of fascism that encompasses its entirety. Simply put, not all fascist scholars agree on its meaning [9]. However, fascism is distinguishable because of the enormous negative moral charge [8]. It involves repression and suppression of political opposition and the use of redemptive violence against ideological rivals to expand influence and power [19]. Britt studied several fascist regimes such as Hitler of Germany, Mussolini of Italy, Franco of Spain, Suharto of Indonesia, and Pinochet of Chile, and found 14 identifying characteristics [9]. Britt's 14 characteristics of fascism match up with Marcuse's (2012) list of 12 emotion based issues used to manipulate the masses towards fascism in the U.S. Marcuse's list includes: anti-abortion and right to life, the right to hold guns, anti-tax measures, homophobia, racism, anti-immigrant sentiment, religious fundamentalism, family values, chauvinist war-mongering, false patriotism, sports fanaticism, and home-ownership [1]. A campaign of manipulation to establish a fascist state differs from the characteristics of a state already in existence, and Marcuse's list is yet the similarities between the two are striking for one is the outgrowth of the former.
Britt's first characteristic is Powerful and Continuing Nationalism. Fascist regimes make constant use of patriotic mottos, slogans, symbols, songs, and other paraphernalia. Flags are seen everywhere, as are flag symbols on clothing and in public displays. This matches with Marcuse's manipulation of False Patriotism [1], [9].

Second is Disdain for the Recognition of Human Rights where people under fascist regimes are persuaded to suspend human rights of scapegoats because fear of scapegoat groups demands suspension to re-establish proper social order. Marcuse does not identify this as an emotion based manipulation, but does cite the groups in the U.S. who will be scapegoats and lose their rights, including homosexuals, immigrants, women, liberals, and people of color [1], [9].

Britt's third characteristic is Identification of Enemies/Scapegoats as a Unifying Cause where people are rallied into a unifying patriotic frenzy over the need to eliminate a perceived common threat or foe: racial, ethnic or religious minorities; liberals; communists; socialists, terrorists, etc. This has a parallel In Marcuse's list for the U.S. where the scapegoats are liberals, women, homosexuals, people of color, and immigrants of color [1], [9].

Britt's fourth characteristic is Supremacy of the Military. Even when there are widespread domestic problems, the military is given a disproportionate amount of government funding, and the domestic agenda is neglected. Soldiers and military service are glamorized. This is a condition of an existing fascist state that grows out of the state being built on a Marcuse's list that includes a campaign of war mongering [1], [9].

Fifth is Rampant Sexism where fascist governments tend to be almost exclusively maledominated and traditional gender roles are made more rigid. Opposition to abortion is high, as is homophobia and anti-gay legislation and national policy. This 'dovetails' with Marcuse's manipulation list where anti-abortion and homophobia are manipulation campaigns [1], [9].

Britt's sixth characteristic is Controlled Mass Media - Sometimes to media is directly controlled by the government, but in other cases, the media is indirectly controlled by government regulation, or sympathetic media spokespeople and executives. Censorship, especially in wartime, is very common. This is not emotional based issue used to manipulate, but represent a condition of the state, so it is not on Marcuse's list of issues [1], [9].

Seventh on Britt's list is Obsession with National Security where fear is used as a motivational tool by the government over the masses. This is made possible by the emotional issue manipulation campaign of chauvinist war mongering. 
Eighth is Religion and Government are Intertwined. Governments in fascist nations tend to use the most common religion in the nation as a tool to manipulate public opinion. Religious rhetoric and terminology are common from government leaders, even when the major tenets of the religion are diametrically opposed to the government's policies or actions. This echoes religious fundamentalism on Marcuse's list [1], [9].

Ninth is Corporate Power is Protected. The industrial and business aristocracies of a fascist nation often are the ones who put the government leaders into power, creating a mutually beneficial business/government relationship and power elite. This represents a condition of an existing and has no parallel to Marcuse's list [1], [9].

Tenth is Labor Power is Suppressed. The organizing power of labor is the only real threat to a fascist government, so labor unions are either eliminated entirely, or are severely suppressed. This takes place after the fascist state is established, so it is not connected to Marcuse's list [1], [9].

Eleventh on Britt's list is Disdain for Intellectuals and the Arts where fascist nations promote and tolerate open hostility to higher education and art. It is not uncommon for professors and other academics to be censored or even arrested. Free expression in the arts is openly attacked, and governments often refuse to fund the arts. This does not parallel a specific emotion based issue on Marcuse's list, but rather derives from an intersection of scapegoats, such as homosexuals, are seen as being in opposition to issues of family values and religious fundamentalism [1], [9].

Number twelve is Obsession with Crime and Punishment. Under fascist regimes, the police are given almost limitless power to enforce laws. The people are often willing to overlook police abuses and even forego civil liberties in the name of patriotism. There is often a national police force with virtually unlimited power in fascist nations, and this represents an outgrowth of militarism where the police serve the military state [1], [9].

Number thirteen is Rampant Cronyism and Corruption. Fascist regimes almost always are governed by groups of friends and associates who appoint each other to government positions and use governmental power and authority to protect their friends from accountability. It is not uncommon in fascist regimes for national resources and even treasures to be appropriated or even outright stolen by government leaders. Again this is a condition in an existing state [9].

Number 14 is Fraudulent Elections. Sometimes elections in fascist nations are a complete sham. Other times elections are manipulated by smear campaigns against or even assassination of opposition candidates, use of legislation to control voting numbers or political district boundaries, and manipulation of the media. Fascist nations also typically use their judiciaries to manipulate or control elections. This is particular to a state in existence and is not germane to Marcuse's list for establishing the fascist state [1], [9].All printed material, including text, illustrations, and charts, must be kept within a print area of 6-1/2 inches $(16.51 \mathrm{~cm})$ wide by $8-7 / 8$ inches $(22.51 \mathrm{~cm})$ high. Do not write or print anything outside the print area. All text must be in a two-column format. Columns are to be $3-1 / 16$ inches $(7.85 \mathrm{~cm})$ wide, with a $3 / 8$ inch $(0.81 \mathrm{~cm})$ space between them. Text must be fully justified.

A format sheet with the margins and placement guides is available as PDF file <format.pdf>. It contains lines and boxes showing the margins and print areas. If you hold it and your printed page up to the light, you can easily check your margins to see if your print area fits within the space allowed.

Do not put page numbers on your document. We will add appropriate page numbers to accepted papers.

Papers must be submitted in Adobe's Portable Document Format (PDF) format. PDF files must not have Adobe Document Protection enabled, as this prevents us from processing the file. These submissions must be formatted to A4 page size, and in first-page-first order. Please verify that the final version of your PDF file prints correctly to a PostScript printer before submission. Also, make sure to disable ALL document security. For best results, authors should avoid the use of custom half tones, bitmap pattern fills, and bitmap fonts. Use standard half tones and solid color or grey fills instead. ALL FONTS MUST be embedded in the PDF file. There is no guarantee that we have the same fonts used in the document.

\section{Methods Section}

To test Marcuse's theory of fascism and its applicability to the 2016 Trump campaign, two variables, racism and gun rights, were selected for brevity's sake from Marcuse's list of manipulation. Two hypotheses were tested, one for each independent variable, to study the effect on the dependent variable, Trump's voting percentage. Hypothesis 1 was Trump's vote percentage would be highest in states with the largest number of white supremacy groups per capita, or the inverse lowest ratio of capita per white supremacy headquarters. Hypothesis 2 was Trump's voting percentage would be highest in states with the highest percentages of households owning a gun. Racism and gun rights were chosen because the two are interrelated with histories of states requiring white males to carry firearms while prohibiting minorities from carrying weapons [18], [19], [20], [23]. Racism is the most developed rhetorical device Trump uses to gain 
support as evidenced by his mantra of "build the wall", "stop the Muslims", and bash the protesting minorities. It is central to his campaign, and it is this centrality of racism that led many GOP leaders to delay or refuse to support/endorsement of the party nominee [22], [23].

Measuring levels of racism and gun rights in a state can be problematic because groups, such as the Klux Klan and the National Rifle Association, do not release membership numbers. However, the Southern Poverty Law Center, SPLC, does have state-by-state data on headquarters for racial supremacy groups, but the focus here is on white supremacy [24]. Consequently, SPLC data was compiled on a state by state basis for white supremacy headquarters that included Ku Klux Klan, Neo Nazis, White nationalists, racist skinheads, Christian identity, and neo Confederates. Headquarters of organizations are a step removed from membership, but are generally a good representation because locations for headquarters are chosen for convenience of proximity to membership in facilitating meetings and communication.

The population of each state, from 2015 U.S. Census data, was then divided by number of headquarters of white supremacy organizations in a state to get a number for persons per white supremacy groups headquarters in each state [25]. Thus, a rural, less densely populated state with a high number of headquarters for White supremacy groups would have a higher capita per headquarter ratio than a more densely populated urban state with a low number of headquarters for white supremacy groups.

Hypothesis 2 looks for a direct relationship where states with higher percentages of households owning a gun will have higher Trump voting percentages. Percentages of households owning guns were obtained from a 2013 study covering 4,000 households in the U.S. by four doctors for Injury Prevention published in 2015 [26]. The percentage of households having gun ownership was correlated with Trump voting percentages using regression. Alaska and Hawaii were problematic outliers both geographically, in relation to the contiguous United States, and also numerically, for the datasets. Thus, Hawaii and Alaska were eliminated from the regression, and the dataset used to for Hypothesis 2 only had an $n=48$.

Statistics for state populations and state presidential election results were gathered from United States Federal sources. For example, state populations were sourced from the U.S. Census Bureau estimates for 2016 that were released in December 2015 [25]. State voting totals were sourced from the Federal Election Commission official results for the 2016 Presidential General Election released in December 2017 with the February 2018 amended Arkansas results [27].
Both SPSS and its open source clone PSPP were used to load data and run calculations for regressions and concomitant statistics to test hypotheses 1 and 2 . SPSS was used to run multiple linear regressions to see if together the independent variables, percentage of households owning a gun and capita per white supremacy headquarters, had a significant impact on the dependent variable, Trump voting percentages.

\section{Results}

Results for both independent variables run by themselves yielded significant numbers impacting the dependent variable, and the power of the impact increased when both independent variables were run together. Run by itself the independent percentage of household owning guns was found to have a direct relationship with Trump voting percentages where Trump voting percentages increased when percentage of households owning guns increased. The Pearson R for percentage of households owning guns was found to be .562 when a level of .2875 was needed at .05 levels of significance and .3721 was needed for a significance level of .01. Adjusted R square was .301 when the $\mathrm{P}$ value was .000 . Thus, the R-value of .562 was nearly double the .2875 level needed to establish significance of a relationship correlation.

Run by itself the independent variable of capita per white supremacy headquarters was found to have an inverse relationship with Trump voting percentages where Trump voting percentages increased when capita per white supremacy headquarters ratio decreased. Thus, the increased number of headquarters per person lowered capita per headquarter ratio. The Pearson $\mathrm{R}$ for capita per headquarters was found to be -.502 when a level of .2875 was needed for .05 levels of significance and .3721 was needed for a significance level of .01. Adjusted R square was .236 when the $\mathrm{P}$ value was .000 . Thus, R-value of -.502 was much greater than the -.2875 level needed to establish significance.

Run by themselves, the independent variables had significant correlations, but they showed an even stronger correlation with Trump voting percentages when they were run together. Run in isolation, the higher Pearson R was .562 for guns per household percentages, but running the two independent variables together the Pearson $\mathrm{R}$ jumped to .659 where the adjusted $\mathrm{R}$ square was .409 for a significance $\mathrm{P}$ of .000 . Thus, the addition of white supremacy hate group headquarters to percentage of households owning guns increased the Pearson R by a factor of $17 \%$.

\section{Discussion}

As evidenced by the two variables, racism and guns rights, used to represent Marcuse's list of 
manipulation used by the wealthy to manipulate the masses to embrace fascism, there is a statistically significant correlation between Trump's voting percentages and number of households owning a gun and capita per white supremacy headquarters. The strongest correlation was when the two variables were run concomitantly in comparison to the two run in isolation. A 17 percent increase in Pearson's R took place when the two were run concomitantly when $\mathrm{R}$ equaled .659 , more than double the .2875 value needed to establish a significant correlation.

The results provide statistical 'fodder' to those asserting the Trump 2016 campaign was fascist at its core [2]. The results also provide evidence critical theory has practical application, even though there are critical theorists who have argued theory should exist for the sake of theory [1]. The application of theory does negate its power of abstraction, but we have interpreted theory for theory's sake as a caution against theory becoming subservient to practical application.

\section{Conclusion}

These correlations are further evidence the 2016 Trump campaign was a fascist endeavor. Critics and commentators can debate whether Trump choosing 'alternative right' people, such as Steve Bannon, to be in his campaign and administration is embracing white supremacy, and whether Trump is channeling violence against the news media, people of color and women. However, it is a different game when you measure the effect on the electorate, millions who make up popular culture, and the effect is racism and fascism form a significant correlation with Trump's state voting percentages. Marcuse's list of manipulation does have power in predicting and explaining real world phenomena. Future research could include test Marcuse's entire list of manipulation.

In 2020, the Trump campaign's fascist pandering has become more extreme and desperate as the COVID pandemic sinks it chances of winning and raises the specter of a Biden Presidency. The President openly encourages his supporters to break the law by voting twice, rise up in violence if he loses, and the majority of voters believe this year's election results will lead to a rise in violence, with many saying it will lead to civil war [28], [29]. His refusal to disavow the white supremacist Proud Boys and calling for paramilitary armed militia's to intimidate voters replays the fascist maneuvers of voter intimidation by the Red Shirts in 1898 that led to the Wilmington Massacre and coup in North Carolina, the same state in which President Trump told voters to vote twice for him [20], [28]. The correlations from the 2016 election results pointing to the Trump's campaign's fascism are merely being confirmed by the violence, intimidation, and law breaking being openly called for by Trump in 2020 .

The potential to use Marcuse's list of manipulation as a continuing classroom exercise could also be tested to see if it increases curriculum retention. In the fall of 2016 the collective light bulb turned on illuminated the rest of the semester because suddenly the material was more alive and the possibility that other theories actually had utility became more of a possibility. As an instructor I surveyed the classroom, and all suspected the list of manipulation would have a correlation, but seeing SPSS run the correlations using election results was chilling. For the purposes of this article the hypotheses tested were in reference to voting totals. However, running this as a classroom exercise for other candidates also has the potential to improve students' understanding of theoretical relevance in application to the real world using statistical methods.

Ultimately, violence is the number one tool in the fascist playbook for it is the foundation for establishing dominance and threats to intimidate others. Possibly the most indemnifying piece of evidence against Trump in this domain are the January 2021 attack on the U.S. Congress because he and his followers were attempting to overthrow the 2020 Presidential results.

\section{References}

[1] Marcuse, P., (2012). 'Whose Right(s) to What City?', in Cities for People, not for Profit, Routledge, New York, NY.

[2] Baker, P., (2016, May 29). 'Rise of Trump Tracks Debate over Fascism', New York Times pp. 1-15.

[3] Christina, G., (2017). 'This Is Not a Drill', Free Inquiry 37(2), pp. 6-7.

[4] Cobble, S., (2016, August 1/8) 'A Step Function Year', The Nation pp. 20-22.

[5] Gilmore, S., (2015). 'Hitler and the Arc of History' Maclean's 128(50), p. 26.

[6] Phippen, J., (2017). 'Trump Returns to the Campaign Trail', https://www.theatlantic.com (21 August 2020).

[7] Paxton, R., (2004). The Anatomy of Fascism, Alfred A. Knopf, New York.

[8] Tomasky, M., (2019). If We Can Keep It: How the Republic Collapsed and How it Might be Saved, Liveright Publishing, New York.

[9] Britt, L., (2004). 'Characteristics of Fascism', Australian Socialist Vol. 13, Issue 2, p. 22.

[10] Berezin, M., (2019). 'Fascism and Populism: Are They Useful Categories for Comparative Sociological 
Analysis?', Annual Review of Sociology Vol. 45, pp. 345361.

[11] Griffin, R., (1996). The Nature of Fascism, Routledge, New York.

[12] Berlin, I. et al. (1968). 'To Define Populism', Government and Opposition Vol 3, No. 2, pp. 137-179.

[13] Beresford, A., Berry, M., and Mann, L. (2017) 'Liberation Movements and Stalled Democratic Transitions: Reducing Power in Rwanda and South Africa Through Productive Liminality', Democratization, Vol. 25 Issue 7: pp. 1231-1250.

[14] Kellner D. (1984). 'Critical Theory and the Critique of Fascism', in Herbert Marcuse and the Crisis of Marxism, Palgrave, London.

[15] Astore, R. (2016). 'Defining the Legitimacy and Power of the State Through Weber and Foucault', Inquiries Journal of Social Sciences and Humanities Vol. 8 No. 5, pp. 22-26.

[16] Baranes, A. (2018). 'Veblen's Theory of Political Evolution and the Ultimatum Game: A Radical Institutionalist Understanding of 2016 Presidential Election", Theory in Action Vol. 11, Issue 3, pp. 1-23.

[17] Fredman, S. (2012) 'Ezra Pound and Italian Fascism', History of European Ideas Vol. 18, Issue 5, pp. 818-819.

[18] Curiel, J. (2014-2015). 'The Birth of a Cinematic Storyline Normalizing Violence Against Black Lives', Ethnic Studies Review 37 and 38, pp. 107-133.

[19] Curiel, J. and McMullen, M. (2014). 'Classically Illogical and Currently Illegal: Social Sciences and Humanities Courses Under HB-228', Journal of Behavioural and Social Sciences 1, pp. 49-59.

[20] Takaki, R. (1993). A Different Mirror: A History of Multicultural America, Little, Brown, Boston.

[21] Zinn, H. (1980). A People's History of the United States, Harper \& Row, Publishers, San Francisco.

[22] Chan, M. (2016). 'Donald Trump Refuses to Condemn KKK, Disavow David Duke', http://time.com. (21 August 2020).

[23] Shear, M., M. Haberman, and Schmidt, M. (2016). 'Critics See Stephen Bannon, Trump's Pick for Strategist, as Voice of Racism', www.nytimes.com (21 August 2020).

[24] Southern Poverty Law Center. (2016). 'Active Hate Groups in the United States in 2015', https://www.splcenter.org (21 August 2020).

[25] U.S. Census Bureau, Population Division. (2017). 'Table 1. Annual Estimates of the Resident Population for the United States, Regions, States, and Puerto Rico: April 1, 2010 to July 1, 2015 (NST-EST2015-01)', https://www.census.gov (21 August 2020).
[26] Kalesan, B. et al. (2015). 'Gun Ownership and Social Gun Culture', https://injuryprevention.bmj.com (21 August 2020).

[27] Federal Elections Commission. (2017, December). 'Federal Elections 2016: Election Results for the U.S. President, the U.S. Senate and the U.S. House of Representatives', Federal Election Commission Public Disclosure and Media Relations Division', https://transition.fec.gov (21 August 2020).

[28] BBC News. 'US election: Trump tells North Carolina Voters to Vote Twice', https://www.bbc.com (1 November 2020).

[29] King, L. (2020). 'The Country's Lost Its Mind: Polls Warning of Civil War, Violence Shows Deep Partisan Chasm Over Election', https://www.usatoday.com (1 November 2020). 